Jurnal Health Sains: p-ISSN: 2723-4339 e-ISSN: 2548-1398

Vol. 2, No. 8, Agustus 2021

\title{
HUBUNGAN KECERDASAN EMOSIONAL TERHADAP TINGKAT DEPRESI MAHASISWA FAKULTAS KEDOKTERAN UNIVERSITAS TARUMANAGARA
}

\author{
Teddy Tjahyanto, Ni Kanaya, Grace Keren, Eunike Angellina Mulyadi, Kevin Sanjaya \\ Listiono \\ Universitas Tarumanagara (UNTAR) Jakarta, Indonesia \\ Email: teddy.405190110@stu.untar.ac.id,nikanaya.405190036@stu.untar.ac.id, \\ grace.405190181@stu.untar.ac.id, eunike.405190086@stu.untar.ac.id, \\ kevin.405190119@stu.untar.ac.id
}

\begin{tabular}{ll}
\hline INFO ARTIKEL & ABSTRAK \\
\hline Diterima & World Health Organization (WHO) secara resmi mendeklarasikan \\
5 Agustus 2021 & COVID-19 sebagai pandemi yang menjadi problema kesehatan di dunia. \\
Direvisi & Pembatasan sosial dan kebijakan pemerintah lainnya yang diberlakukan \\
15 Agustus 2021 & selama pandemi COVID-19 untuk menurunkan penyebaran virus yang \\
Disetujui & sangat menular menyebabkan banyak orang mengalami kesepian, \\
25 Agustus 2021 & ketakutan, kecemasan dan berakhir pada depresi. Prevalensi depresi di \\
\hline Kata Kunci: & Indonesia saat pandemi COVID-19 mencapai angka 62\%. Kecerdasan \\
kecerdasan & emosional merupakan kemampuan dalam mengatur dan mengontrol \\
emosional; depresi; & emosi yang dapat berperan dalam menyikapi kebijakan selama pandemi \\
COVID-19 & COVID-19 dan kejadian depresi. Penelitian dilakukan untuk mengetahui \\
& hubungan antara kecerdasan emosional dengan depresi pada mahasiswa \\
& Fakultas Kedokteran Universitas Tarumanagara angkatan 2019. \\
& Menggunakan desain penelitian deskriptif analitik dengan pendekatan \\
& cross-sectional, kami memperoleh data melalui simple random sampling \\
& sebanyak 154 responden yang menjawab kuesioner kecerdasan \\
& emosional yang digunakan sebagai proksi dalam menentukan skala \\
& kecerdasan emosional. Hasil chi-square hubungan kecerdasan emosional \\
& dengan depresi didapatkan p-value 0.003. Berdasarkan hasil penelitian \\
& didapatkan bahwa terdapat hubungan yang bermakna antara kecerdasan \\
& emosional dan depresi pada mahasiswa saat pandemi COVID-19. Oleh \\
& karena itu, diharapkan mahasiswa dapat meningkatkan kecerdasan \\
& emosional yang mereka miliki sebagai upaya preventif akan terjadinya \\
& depresi.
\end{tabular}

\begin{abstract}
The World Health Organization (WHO) recognize the COVID-19 pandemic as an imminent global threat. To dampen the spread of the highly-contagious virus, the Indonesian government has imposed several social-distancing and government regulations. Nonetheless, these regulations result in peripheral effects; many people are subject to loneliness, fear, and anxiety - all of which leads to depression. Statistical evidence show that depression is very much prevalent in Indonesians-reaching a staggering 62\% as of August 2020. Multiple studies have proven the negative correlation between emotional intelligence - which is the ability to regulate and control emotions - and depression. Consequently, this study aims to determine the relationship between emotional intelligence and depression in medical students of
\end{abstract}

$\begin{array}{ll}\text { How to cite: } & \text { Tjahyanto Teddy. et,al. (2021) Hubungan Kecerdasan Emosional terhadap Tingkat Depresi } \\ & \begin{array}{l}\text { Mahasiswa Fakultas Kedokteran Universitas Tarumanagara. Jurnal Health Sains 2(8). } \\ \text { https://doi.org/10.46799/jhs.v2i8.259 }\end{array} \\ \text { E-ISSN: } & 2723-6927 \\ \text { Published by: } & \text { Ridwan Institute }\end{array}$




\begin{tabular}{ll}
\hline & Universitas Tarumanagara batch 2019. Using a descriptive analytic \\
& research design with a cross-sectional approach, we obtained data \\
& through simple random sampling a total of 154 respondents who \\
& answered an emotional intelligence questionnaire used as a proxy in \\
& determining the level of emotional intelligence. Statistical analysis using \\
Keywords: & the chi-square test confirmed that there is a significant negative \\
emotional & correlation between emotional intelligence and depression during the \\
intelligence; & COVID-19 pandemic, yielding a p-value of 0.003. In conclusion, \\
depression; COVID- & students can improve their level of emotional intelligence as a preventive \\
19 & measure of depression during the COVID-19 pandemic.
\end{tabular}

\section{Pendahuluan}

World Health Organization (WHO) menginformasikan adanya kasus pneumonia dengan penyebab yang tidak diketahui di Wuhan, Cina pada tanggal 31 Desember 2019. Beberapa minggu kemudian pada Januari 2020, hasil analisis mendalam dari sampel saluran pernafasan bagian bawah mendeteksi virus baru yakni Severe Acute Respiratory Syndrome Coronavirus 2 (SARSCoV-2) yang menyebabkan Coronavirus Disease 2019 (COVID-19). Pada tanggal 11 Maret 2020, COVID-19 telah menyebar ke 114 negara dan telah menyebabkan 4000 kematian sehingga WHO secara resmi mendeklarasikan COVID-19 sebagai pandemi (Di Gennaro et al., 2020).

Berdasarkan data Satuan Tugas Penanganan COVID-19 (SATGAS COVID19), pada tanggal 25 Juli 2021, COVID-19 telah menyebar ke 223 negara dengan total kasus 192.284.207 dan 4.136.518 kematian. Di Indonesia, COVID-19 sudah tersebar di 34 provinsi dengan kasus positif sebanyak 3.166.505 dan kematian sebanyak 83.279 jiwa (Covid, 2019).

Fenomena sosial COVID-19 sangat bergantung dengan pembatasan kontak sosial yang efektif untuk menurunkan penyebaran virus yang sangat menular (Marroquín et al., 2020). WHO merekomendasikan prosedur social distancing yang dapat meminimalisir kontak sosial dan fisik antara masyarakat yang meliputi penutupan bisnis yang tidak esensial, kerja jarak jauh, pembelajaran jarak jauh, dan lain-lain (Oosterhoff et al., 2020).
Pemerintah menerapkan Pembatasan Sosial Berskala Besar (PSBB) yang peraturannya melingkupi, pembatasan kegiatan keagamaan, kegiatan sosial dan budaya dan kegiatan di tempat atau fasilitas umum dimana restoran dan warung makan dibatasi kapasitasnya. Namun, akibat terjadinya peningkatan kasus yang signifikan, pemerintah menerapkan Pemberlakuan Pembatasan Kegiatan Masyarakat (PPKM), dimana pelaksanaan kegiatan pada sektor non esensial diberlakukan $100 \%$ kerja dan pembelajaran jarak jauh. Selebihnya, pemerintah juga mengharuskan menutup pusat perbelanjaan/pusat perdagangan; tempat ibadah; fasilitas umum; sarana kegiatan seni/budaya, olahraga, sosial kemasyarakatan, dan restoran untuk tidak menerima makan ditempat. Kebijakan yang mengharuskan siswa dan mahasiswa melaksanakan kegiatan pembelajaran jarak jauh bertujuan untuk memenuhi hak peserta didik untuk mendapatkan layanan pendidikan selama darurat COVID-19, melindungi warga satuan pendidikan dari dampak buruk COVID-19, mencegah penyebaran dan penularan COVID-19 di satuan pendidikan dan memastikan pemenuhan dukungan psikososial bagi pendidik, didik, dan orang tua (Covid-19, 2020, 2021; M. D. N. R. Indonesia, 2021; M. K. R. Indonesia, 2020).

Pemberlakuan pembatasan sosial, meningkatnya kasus positif dan kematian dengan cepat, dan berita media sosial yang melonjak selama pandemi dapat berdampak pada kesehatan mental populasi umum, salah 
satunya pada mahasiswa kedokteran yang harus melewati tekanan signifikan, seperti jam belajar yang panjang, beban kerja yang berat dan masalah ekonomi yang cukup besar (V \& M, 2014). Berdasarkan penelitian mengenai true quarantine, karantina menyebabkan efek substansial pada tekanan emosional dan kesehatan mental yang meliputi depresi, kecemasan, insomnia, dan stres pasca trauma (Li et al., 2020; Marroquín et al., 2020; Xiang et al., 2020).

Depresi merupakan sebuah gangguan mood yang gejalanya dapat mempengaruhi pikiran, perasaan, aktivitas sehari-hari seperti pola tidur, pola makan dan pekerjaan. Orang didiagnosis mengalami depresi ketika gejala menetap selama paling tidak dua minggu (Corbett, 2018). Berdasarkan penelitian oleh Perhimpunan Dokter Spesialis Kedokteran Jiwa Indonesia (PDSKJI), didapatkan sebanyak $64.8 \%$ responden mengalami masalah psikologis dengan $75 \%$ mengalami trauma, 65\% mengalami kecemasan, dan 62\% mengalami depresi selama lima bulan berlangsungnya pandemi COVID-19 di Indonesia. Masalah psikologis terbanyak ditemukan pada kelompok usia 17-29 tahun dan >60 tahun (PDSKJI, 2020). Sepanjang pandemi COVID-19, puncak tekanan mental berkorelasi erat dengan puncak kematian COVID-19 dan periode ketika tindakan pengendalian pandemi paling ketat. Kejadian ini membaik dengan penurunan kasus COVID-19 dan pelonggaran pembatasan sosial (OECD, 2021).

Kecerdasan emosional adalah kemampuan seseorang untuk mengatur dan mengontrol emosi, bukan hanya dari diri mereka namun juga orang-orang di sekitarnya (Thakur, 2020). Orang yang memiliki kecerdasan emosional tinggi juga memiliki passion, pengendalian diri, ketekunan, mampu memotivasi diri sendiri, dan lebih mudah pulih dari kegagalan dan kesedihan, sedangkan orang dengan kecerdasan emosional yang rendah, seringkali mudah mengalami depresi dan melawan perasaan sendiri. (D. Goleman, 2009). Kecerdasan emosional memiliki lima elemen: kesadaran diri, pengaturan diri, motivasi, empati, dan kompetensi sosial. Kesadaran diri adalah kemampuan untuk mengenali dan memahami emosi, suasana hati, dan dorongan (drive) seseorang serta bagaimana semua ini mempengaruhi orang lain. Pengaturan diri adalah kemampuan untuk mengendalikan emosi atau respons yang mengganggu. Motivasi mengacu pada dorongan untuk bekerja menuju tujuan. Empati melibatkan kemampuan untuk memahami dan menerima emosi, suasana hati, dan dorongan orang lain. Keterampilan sosial merupakan kemampuan untuk mengelola hubungan dan jaringan (network) dengan orang lain melalui kesamaan diantaranya (common ground). Guna mengelola emosi secara lebih positif dan mencegah depresi, individu dapat memahami emosinya untuk memfasilitasi pemikiran, memahami emosi, memberi makna pada pengalaman emosional, dan mengatur emosi (Zoromba et al., 2015).

Banyak orang mengalami kecemasan, kesepian, ketakutan, dan emosi negatif oleh karena adanya pembatasan sosial yang diberlakukan selama pandemi COVID-19. Kecemasan yang berkepanjangan dapat mengakibatkan terjadinya gangguan kesehatan mental yakni depresi. Sehubungan dengan hal tersebut, orang dengan kecerdasan emosional yang tinggi mempunyai kemampuan beradaptasi yang lebih baik, salah satunya karena mereka cenderung mempunyai support system yang kuat. (Drigas \& Papoutsi, 2020).

Oleh karena itu, melihat adanya permasalahan terhadap depresi yang dialami oleh individu dalam melakukan pembelajaran jarak jauh, penelitian hendak dilakukan lebih lanjut untuk mengetahui hubungan kecerdasan emosional terhadap tingkat depresi mahasiswa Fakultas Kedokteran 
Teddy Tjahyanto, Ni Kanaya, Grace Keren, Eunike Angellina Mulyadi, Kevin Sanjaya Listiono

Universitas Tarumanagara angkatan 2019 selama pandemi COVID-19.

\section{Metode Penelitian}

Penelitian ini menggunakan metode penelitian studi survei analitik dengan desain penelitian cross-sectional. Survei analitik adalah penelitian yang mencoba menggali bagaimana dan mengapa fenomena itu terjadi, kemudian dilakukan analisis dinamika korelasi antara fenomena atau antara faktor risiko dengan faktor efek. Dari analisis korelasi tersebut dapat diketahui seberapa jauh kontribusi faktor risiko terhadap adanya suatu kejadian tertentu (Notoatmodjo, 2018). Desain penelitian cross-sectional adalah pengambilan data variabel dependen dan variabel independen yang dilakukan pada saat yang bersamaan. Variabel independen merupakan variabel yang dimanipulasi oleh peneliti, dan variabel dependen akan berubah akibat manipulasi tersebut (Notoatmodjo, 2014).

Pemilihan sampel pada mahasiswa Fakultas Kedokteran

Universitas Tarumanagara angkatan 2019 menggunakan teknik simple random sampling dengan jumlah sampel 154 responden yang telah dilakukan pada bulan Juni 2021. Simple random sampling adalah teknik mengambil secara acak dari anggota populasi sehingga semua orang memiliki probabilitas yang sama untuk menjadi bagian dari sampel (Popov, 2018).

Teknik pengumpulan data pada penelitian ini dilakukan secara online menggunakan platform Google Forms dengan cara memberikan daftar pertanyaan dan pilihan jawaban. Analisis bivariat dengan uji chi-square digunakan untuk melihat pengaruh tingkat kecerdasan emosional terhadap depresi dengan tingkat kepercayaan $95 \%$.

Data yang dikumpulkan dalam penelitian ini adalah data primer yang diperoleh secara langsung dari sumber informasi dengan menggunakan instrumen kuesioner secara daring. Kuesioner yang digunakan adalah PHQ-9 dan Kecerdasan Emosional. Hasil kuesioner PHQ-9 dalam bentuk kategori Normal, Ringan, Sedang, Sedang berat, dan Berat dengan nilai cut-off $\geq 10$ dinyatakan depresi (Urtasun et al., 2019). Kuesioner Kecerdasan Emosional menggunakan skala Likert untuk mengukur variabel penelitian dalam pilihan jawaban yang terdiri dari Sangat Tidak Setuju (STS), Tidak Setuju (TS), Setuju (S), dan Sangat Setuju (SS) dengan kategori hasil tinggi dan rendah.

\section{Hasil dan Pembahasan}

\section{A. Hasil Penelitian}

Analisis univariat dilakukan untuk melihat distribusi variabel yang ada pada penelitian. Variabel independen pada penelitian ini yaitu depresi dan kecerdasan emosional.

Tabel 1

Frekuensi Depresi

\begin{tabular}{lll}
\hline Variabel & \multicolumn{2}{c}{ Frekuensi } \\
& n & \% \\
\hline Tidak Depresi & 123 & 79,9 \\
\hline Depresi & 31 & 20,1 \\
\hline Total & 154 & 100.0 \\
\hline
\end{tabular}

Berdasarkan tabel 1, dari 154 mahasiswa Fakultas Kedokteran Universitas Tarumanagara angkatan 2019, sebanyak 31 orang $(20.1 \%)$ mengalami depresi dan sebanyak 123 orang $(79,9 \%)$ tidak mengalami depresi.

Tabel 2

Frekuensi Kecerdasan Emosional

\begin{tabular}{lll}
\hline Variabel & \multicolumn{2}{c}{ Frekuensi } \\
& n & \% \\
\hline Tinggi & 46 & 29,9 \\
\hline Rendah & 108 & 70,1 \\
\hline Total & 154 & 100.0 \\
\hline
\end{tabular}

Kecerdasan emosional dapat dibagi menjadi dua yaitu kecerdasan emosional 
tinggi dan rendah. Berdasarkan hasil distribusi frekuensi kecerdasan emosional dalam tabel 2, terdapat mahasiswa dengan kecerdasan emosional tinggi sebanyak 46 orang $(29.9 \%)$ dan kecerdasan emosional yang rendah sebanyak 108 orang $(70.1 \%)$.

Tabel 3

Hubungan Jenis Kelamin dan Kecerdasan Emosional

\begin{tabular}{cccccccc}
\hline \multirow{2}{*}{$\begin{array}{c}\text { Jenis } \\
\text { Kelamin }\end{array}$} & \multicolumn{2}{c}{ Kecerdasan Emosional } & \multicolumn{2}{c}{ Total } & \\
\cline { 2 - 5 } & \multicolumn{2}{c}{ Tinggi } & \multicolumn{2}{c}{ Rendah } & & & $p-$ \\
\cline { 2 - 5 } & $\mathrm{n}$ & $\%$ & $\mathrm{n}$ & $\%$ & $\mathrm{n}$ & $\%$ & value \\
\hline Pria & 18 & 40,9 & 26 & 59,1 & 44 & 29 & \\
\hline Wanita & 28 & 25,5 & 82 & 74,5 & 110 & 71 & 0,089 \\
\hline
\end{tabular}

Berdasarkan tabel 3, dari 44 mahasiswa dengan jenis kelamin pria didapatkan 18 orang (40.9\%) memiliki kecerdasan emosional tinggi dan 26 orang (59.1\%) memiliki kecerdasan emosional rendah. Dari 110 mahasiswa dengan jenis kelamin wanita didapatkan 28 orang (25.5\%) memiliki kecerdasan emosional tinggi dan 82 orang (74.5\%) memiliki kecerdasan emosional rendah. Berdasarkan hasil analisis uji chi-square diperoleh bahwa jenis kelamin ( $\mathrm{p}$-value 0.089) tidak berhubungan secara signifikan dengan kecerdasan emosional yang ditentukan nilai $p$-value $>0,05$ dan OR 2,027 dengan derajat kepercayaan $95 \%$, artinya jenis kelamin tidak berpengaruh terhadap tingkat kecerdasan emosional.

\section{Tabel 4}

Hubungan Kecerdasan Emosional dan Depresi

\begin{tabular}{cccccccc}
\hline & \multicolumn{4}{c}{ Depresi } & \multicolumn{3}{c}{ Total } \\
\cline { 2 - 7 } $\begin{array}{c}\text { Kecerdasan } \\
\text { Emosional }\end{array}$ & $\begin{array}{c}\text { Tidak } \\
\text { Depresi }\end{array}$ & \multicolumn{2}{c}{ Depresi } & & & \\
\cline { 2 - 7 } & $\mathbf{n}$ & $\%$ & n & $\%$ & n & \% & $\begin{array}{c}\text { p- } \\
\text { value }\end{array}$ \\
\hline Tinggi & 44 & 95,7 & 2 & 4,3 & 46 & 29,9 & 0,003 \\
\hline Rendah & 79 & 73,1 & 29 & 26,9 & 108 & 70,1 & \\
\hline
\end{tabular}

Berdasarkan tabel 4, dari 46 mahasiswa yang memiliki kecerdasan emosional tinggi didapatkan tidak mengalami depresi sebanyak 44 orang (95.7\%) dan mengalami depresi sebanyak 2 orang (4.3\%), lalu dari 108 mahasiswa yang memiliki kecerdasan emosional rendah didapatkan tidak mengalami depresi sebanyak 79 orang $(73.1 \%)$ dan mengalami depresi sebanyak 29 orang (26.9\%). Hasil analisis uji chi-square diperoleh nilai $\mathrm{p}$-value $0.003(\mathrm{p}<0,05)$ dan nilai OR 8,076 dengan derajat kepercayaan 95\%, artinya kecerdasan emosional berpengaruh pada tingkat depresi.

\section{B. Pembahasan}

Kecerdasan emosional adalah faktor prediktif potensial dalam depresi karena terdapat sebanyak $64 \%$ varian depresi dalam kecerdasan emosional yaitu varian harga diri dan kemampuan pemecahan masalah (Batool \& Khalid, 2009). Dalam penelitian ini didapatkan bahwa semakin rendah kecerdasan emosional, maka semakin tinggi depresi dengan p-value 0.003 ( $\mathrm{p}<0,05)$. Hal ini didukung oleh (Goleman, 2009), apabila seseorang dapat meningkatkan kecerdasan emosional maka dapat menurunkan risiko terjadinya depresi. Sejalan dengan penelitian yang dilakukan oleh (Ramdhani et al., 2020), dimana ada hubungan yang bermakna negatif dengan korelasi sedang antara tingkat kecerdasan emosi dengan derajat depresi pada mahasiswa kedokteran tahun pertama Program Studi Kedokteran Universitas Sebelas Maret tahun 2020.

Berdasarkan analisis penelitian ini didapatkan hubungan yang tidak signifikan antara jenis kelamin dengan tingkat kecerdasan emosional ( $p>0,05)$. Pada studi (Meshkat \& Nejati, 2017) didapatkan kecerdasan emosional tidak secara signifikan berbeda antara pria dan wanita, namun jenis kelamin memiliki perbedaan dalam kesadaran emosional, hubungan interpersonal, harga diri, dan 
empati dengan skor wanita lebih tinggi daripada pria. Harga diri pada pria cenderung memiliki skor lebih tinggi. Selain itu, Abe et al menyatakan bahwa kecerdasan emosional dipengaruhi oleh sifat seseorang dan bukan dari jenis kelamin. Penelitian (Sundararajan \& Gopichandran, 2018) juga menyatakan bahwa pria dan wanita mempunyai kemampuan yang sama dalam mengidentifikasi dan mengatur emosi mereka dengan orang lain. Namun, berdasarkan (Ahmad et al., 2009), pria berasosiasi dengan kecerdasan emosional yang lebih tinggi dibandingkan wanita $(p<0,01)$. Hal ini dikarenakan pria mempunyai kepribadian yang cenderung lebih asertif, independen, dan kemampuan yang lebih baik dalam menghadapi situasi sulit.

Gangguan depresi meningkat secara signifikan pada berbagai sektor dalam keadaan pandemi COVID-19 (Czeisler et al., 2020). Pelaksanaan belajar jarak jauh dapat berdampak terhadap kesehatan mental dan kondisi belajar pada mahasiswa kedokteran. Sebelum adanya pandemi COVID-19, tekanan mental merupakan hal yang umum di kalangan mahasiswa kedokteran, seperti kecemasan, depresi, dan tekanan psikologis. Pada kondisi mahasiswa kedokteran yang melakukan pembelajaran dengan mengunjungi rumah sakit didapatkan kecemasan menurun setelah melakukan pembelajaran daring, namun kecemasan pada mahasiswa non kedokteran meningkat. Hal ini menunjukan risiko tinggi persepsi COVID-19 berkontribusi pada tingkat kecemasan (B et al., 2020). Berdasarkan hasil penelitian (Halperin et al., 2021) pada mahasiswa kedokteran, didapatkan bahwa selama pandemi COVID-19 mahasiswa kedokteran mengalami peningkatan tingkat depresi sebesar 70\%, maka dari itu dapat dilihat perbedaan tingkat depresi yang signifikan pada mahasiswa kedokteran tingkat preklinik selama pandemi COVID-19. Namun, berdasarkan penelitian oleh (A et al., 2020) pada mahasiswa kedokteran stase klinis, didapatkan perbedaan tingkat depresi sebelum dan sesudah COVID-19 yang tidak signifikan karena adanya tindakan meminimalkan kehadiran mahasiswa terhadap paparan pasien COVID-19 dengan pembelajaran daring yang dapat membantu mengendalikan gejala kecemasan dan depresi.

Telah diketahui bahwa kecerdasan emosional mempunyai peran penting dalam mencegah terjadinya depresi, terutama saat pandemi COVID-19. Terdapat beberapa metode yang dapat meningkatkan kecerdasan emosional. SelfRegulated Learning adalah metode yang menekankan siswa untuk memiliki kemandirian dan motivasi dalam menyelesaikan berbagai masalah (Awaluddin, Muthmainnah, \& Ali, 2014). Situation, Options, Consequences, Solutions (SOCS) merupakan metode berpikir dimana pertama kita harus mengenali situasi yang kita hadapi dan perasaan kita, berpikir tentang solusi untuk mengatasi situasi tersebut beserta konsekuensi dari setiap solusi, dan yang terakhir adalah melaksanakan solusi yang dipilih. Kurikulum Parents and Teacher Helping Students (PATH) mengajarkan tentang bagaimana cara mengenal berbagai emosi dan cara mengendalikannya. Terakhir, Emotional Literacy Classes mengajarkan cara mengenal emosi, manajemen emosi, memahami emosi orang sekitar, dan cara mempertahankan relasi (M. Goleman et al., 2019). Keterbatasan dari penelitian ini adalah proporsi laki-laki dan perempuan yang tidak seimbang, respon objektif terhadap kuesioner survei dan data yang menunjukan status mental responden 
hanya pada titik waktu tertentu dan tidak mengikuti perkembangan depresi responden.

\section{Kesimpulan}

Berdasarkan hasil penelitian dan pembahasan yang telah diuraikan, dapat disimpulkan bahwa distribusi frekuensi dari 154 orang mahasiswa Fakultas Kedokteran Universitas Tarumanagara angkatan 2019, diketahui 46 (29,9\%) mahasiswa memiliki kecerdasan emosional tinggi, dan 108 $(70,1 \%)$ mahasiswa memiliki kecerdasan emosional yang rendah. Berdasarkan distribusi frekuensi dari 154 orang, diketahui $31(20,1 \%)$ orang mengalami depresi, dan $123(79.9 \%)$ tidak mengalami depresi. Dari 44 mahasiswa dengan jenis kelamin pria didapatkan 18 orang (40.9\%) memiliki kecerdasan emosional tinggi dan 26 orang (59.1\%) memiliki kecerdasan emosional rendah. Dari 110 mahasiswa dengan jenis kelamin wanita didapatkan 28 orang (25.5\%) memiliki kecerdasan emosional tinggi dan 82 orang $(74.5 \%)$ memiliki kecerdasan emosional rendah. Terdapat hubungan yang tidak bermakna antara jenis kelamin dengan kecerdasan emosional (p-value 0,089) dan OR 2,027 dengan derajat kepercayaan 95\%, artinya jenis kelamin tidak berpengaruh terhadap tingkat kecerdasan emosional. Dari 46 mahasiswa yang memiliki kecerdasan emosional tinggi didapatkan tidak mengalami depresi sebanyak 44 orang $(95.7 \%)$ dan mengalami depresi sebanyak 2 orang $(4.3 \%)$, lalu dari 108 mahasiswa yang memiliki kecerdasan emosional rendah didapatkan tidak mengalami depresi sebanyak 79 orang (73.1\%) dan mengalami depresi sebanyak 29 orang $(26.9 \%)$. Terdapat hubungan bermakna antara kecerdasan emosional dengan tingkat depresi (p-value 0.003) dan nilai OR 8,076 dengan derajat kepercayaan 95\%, artinya kecerdasan emosional berpengaruh pada tingkat depresi.

\section{BIBLIOGRAFI}

Ahmad, S., Bangash, H., \& Khan, S. A. (2009). Emotional Intelligence And Gender Differences. Sarhad J. Agric, 25(1), 127-130. Google Scholar

Batool, S. S., \& Khalid, R. (2009). Low Emotional Intelligence: A Risk Factor For Depression. Journal of Pakistan Psychiatric Society, 6(2), 65-72. Google Scholar

Corbett, D. (2018). Nimh - Depression. In 2018. Google Scholar

Covid-19, G. T. (2020). Kebijakan Psbb Pilihan Paling Rasional Di Tengah Covid-19 - Berita Terkini | Covid19.Go.Id. Covid19.Go.Id. Google Scholar

Covid-19, G. T. (2021). Inilah Aturan Lengkap Ppkm Darurat (3-20 Juli 2021) - Masyarakat Umum | Covid19.Go.Id. Covid19.Go.Id. Google Scholar

Covid, K. P. (2019). Dan Pemulihan Ekonomi Nasional.(2020). Jaring Pengaman Sosial Pemerintah Pusat Hadapi Covid19-Masyarakat Umum Satgas Penanganan Covid-19. Google Scholar

Czeisler, M. É., Lane, R. I., Petrosky, E., Wiley, J. F., Christensen, A., Njai, R., Weaver, M. D., Robbins, R., FacerChilds, E. R., \& Barger, L. K. (2020). Mental Health, Substance Use, And Suicidal Ideation During The Covid-19 Pandemic - United States, June 24-30, 2020. Morbidity And Mortality Weekly Report, 69(32), 1049. Google Scholar

Di Gennaro, F., Pizzol, D., Marotta, C., Antunes, M., Racalbuto, V., Veronese, N., \& Smith, L. (2020). Coronavirus Diseases (Covid-19) Current Status And Future Perspectives: A Narrative Review. International Journal of Environmental Research And Public Health, 17(8), 2690. Google Scholar 
Teddy Tjahyanto, Ni Kanaya, Grace Keren, Eunike Angellina Mulyadi, Kevin Sanjaya Listiono

Drigas, A., \& Papoutsi, C. (2020). The Need For Emotional Intelligence Training Education In Critical And Stressful Situations: The Case Of Covid-19. International Journal of Recent Contributions From Engineering, Science \& It (Ijes), 8(3), 20-36. Google Scholar

Goleman, D. (2009). Emotional Intelligence Why It Can Matter More Than Iq. Bloomsbury Publishing Plc. Google Scholar

Goleman, M., Balicki, I., Radko, A., Jakubczak, A., \& Fornal, A. (2019). Genetic Diversity Of The Polish Hunting Dog Population Based On Pedigree Analyses And Molecular Studies. Livestock Science, 229, 114117. Google Scholar

Halperin, S. J., Henderson, M. N., Prenner, S., \& Grauer, J. N. (2021). Prevalence Of Anxiety And Depression Among Medical Students During The Covid-19 Pandemic: A Cross-Sectional Study. Journal of Medical Education And Curricular Development, 8, 2382120521991150. Google Scholar

Indonesia, M. D. N. R. (2021). Instruksi Menteri Dalam Negeri Nomor 03 Tahun 2021 Tentang Psbb Mikro. Google Scholar

Indonesia, M. K. R. (2020). Peraturan Menteri Kesehatan Republik Indonesia. In Peraturan Menteri Kesehatan Republik Indonesia (Vol. 9). Google Scholar

Li, S., Wang, Y., Xue, J., Zhao, N., \& Zhu, T. (2020). The Impact Of Covid-19 Epidemic Declaration On Psychological Consequences: A Study On Active Weibo Users. International Journal of Environmental Research And Public Health, 17(6). Google Scholar

Marroquín, B., Vine, V., \& Morgan, R. (2020). Mental Health During The
Covid-19 Pandemic: Effects Of Stay-AtHome Policies, Social Distancing Behavior, And Social Resources. Psychiatry Research, 293, 113419. Google Scholar

Meshkat, M., \& Nejati, R. (2017). Does Emotional Intelligence Depend On Gender? A Study On Undergraduate English Majors Of Three Iranian Universities. Sage Open, 7(3), 2158244017725796. Google Scholar

Notoatmodjo, S. (2014). Metodologi Penelitian Kesehatan. Pt Rineka Cipta. Google Scholar

Notoatmodjo, S. (2018). Metodologi Penelitian Kesehatan (3rd Ed.). Pt Rineka Cipta. Google Scholar

Oecd. (2021). Tackling The Mental Health Impact of The Covid-19 Crisis: An Integrated, Whole-Of-Society Response. May, 1-16. Google Scholar

Oosterhoff, B., Palmer, C. A., Wilson, J., \& Shook, N. (2020). Adolescents' Motivations To Engage In Social Distancing During The Covid-19 Pandemic: Associations With Mental And Social Health. Journal of Adolescent Health, 67(2), 179-185. Google Scholar

Pdskji. (2020). Pdskji | Pdskji.Org. Google Scholar

Popov, A. (2018). Psychology (2nd Ed.). Oxford University Press 2018. Google Scholar

Ramdhani, S. F., Fanani, M., \& Nugroho, D. (2020). Hubungan Tingkat Kecerdasan Emosi Dengan Derajat Depresi Pada Mahasiswa Kedokteran. Wacana, 12(1), 110-132. Google Scholar

Sundararajan, S., \& Gopichandran, V. (2018). Emotional Intelligence Among Medical Students: A Mixed Methods Study From Chennai, India. Bmc Medical Education, 18(1), 1-9. Google Scholar 
Hubungan Kecerdasan Emosional terhadap Tingkat Depresi Mahasiswa Fakultas Kedokteran Universitas Tarumanagara

963-979. Google Scholar

Thakur, M. (2020). Importance Of Emotional Intelligence _ Features And Components Of Ei. Google Scholar

Urtasun, M., Daray, F. M., Teti, G. L., Coppolillo, F., Herlax, G., Saba, G., Rubinstein, A., Araya, R., \& Irazola, V. (2019). Validation And Calibration Of The Patient Health Questionnaire (Phq9) In Argentina. Bmc Psychiatry 2019 19:1, 19(1), 1-10. Google Scholar

V, H., \& M, H. (2014). Medical Student Depression, Anxiety And Distress Outside North America: A Systematic Review. Medical Education, 48(10),
Xiang, Y.-T., Yang, Y., Li, W., Zhang, L., Zhang, Q., Cheung, T., \& Ng, C. H. (2020). Timely Mental Health Care For The 2019 Novel Coronavirus Outbreak Is Urgently Needed. The Lancet. Psychiatry, 7(3), 228. Google Scholar

Zoromba, M., Abdellatif, S., Hussien, E., \& Hamed, W. (2015). Relationship Between Emotional Intelligence And Levels Of Depression Among Patients With Depressive Disorders. Mansoura Nursing Journal, 2(4), 45-54. 128 Google Scholar

\section{Copyright holder:}

Teddy Tjahyanto, Ni Kanaya, Grace Keren, Eunike Angellina Mulyadi dan Kevin Sanjaya Listiono (2021)

First publication right:

Jurnal Health Sains

This article is licensed under:

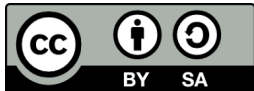

